\title{
GPS RECEIVERS FOR GEOREFERENCING OF SPATIAL VARIABILITY OF SOIL ATTRIBUTES
}

\section{DAVID L. ROSALEN ${ }^{1}$, MARCOS S. RODRIGUES ${ }^{2}$, CARLOS A. CHIODEROLI ${ }^{3}$, FLAVIA J. C. BRANDÃO ${ }^{4}$, DIEGO S. SIQUEIRA ${ }^{5}$}

\begin{abstract}
The characterization of the spatial variability of soil attributes is essential to support agricultural practices in a sustainable manner. The use of geostatistics to characterize spatial variability of these attributes, such as soil resistance to penetration (RP) and gravimetric soil moisture $(\mathrm{GM})$ is now usual practice in precision agriculture. The result of geostatistical analysis is dependent on the sample density and other factors according to the georeferencing methodology used. Thus, this study aimed to compare two methods of georeferencing to characterize the spatial variability of RP and GM as well as the spatial correlation of these variables. Sampling grid of 60 points spaced $20 \mathrm{~m}$ was used. For RP measurements, an electronic penetrometer was used and to determine the GM, a Dutch auger (0.0-0.1 m depth) was used. The samples were georeferenced using a GPS navigation receiver, Simple Point Positioning (SPP) with navigation GPS receiver, and Semi-Kinematic Relative Positioning (SKRP) with an L1 geodetic GPS receiver. The results indicated that the georeferencing conducted by PPS did not affect the characterization of spatial variability of RP or GM, neither the spatial structure relationship of these attributes.
\end{abstract}

KEYWORDS: precision agriculture, GNSS, compaction, soil water content.

\section{RECEPTORES GPS PARA GEORREFERENCIAMENTO DA VARIABILIDADE ESPACIAL DE ATRIBUTOS DO SOLO}

RESUMO: A caracterização da variabilidade espacial dos atributos do solo é indispensável para subsidiar práticas agrícolas de maneira sustentável. A utilização da geoestatística para caracterizar a variabilidade espacial desses atributos, como a resistência mecânica do solo à penetração $(\mathrm{RP})$ e a umidade gravimétrica do solo (UG), é, hoje, prática usual na agricultura de precisão. O resultado da análise geoestatística é dependente da densidade amostral e de outros fatores, como o método de georreferencimento utilizado. Desta forma, o presente trabalho teve como objetivo comparar dois métodos de georreferenciamento para a caracterização da variabilidade espacial da RP e da UG, bem como a correlação espacial dessas variáveis. Foi implantada uma malha amostral de 60 pontos, espaçados em $20 \mathrm{~m}$. Para as medições da RP, utilizou-se de penetrógrafo eletrônico e, para a determinação da UG, utilizou-se de trado holandês (profundidade de 0,0-0,1 m). As amostras foram georreferenciadas, utilizando-se do método de Posicionamento por Ponto Simples (PPS), com de (retirar) receptor GPS de navegação, e Posicionamento Relativo Semicinemático, com receptor GPS geodésico L1. Os resultados indicaram que o georreferenciamento realizado pelo PPS não interferiu na caracterização da variabilidade espacial da RP e da UG, assim como na estrutura espacial da relação dos atributos.

PALAVRAS-CHAVE: agricultura de precisão, GNSS, compactação, teor de água.

\footnotetext{
${ }^{1}$ Eng $^{\mathrm{o}}$ Agrônomo, Prof. Dr., Departamento de Engenharia Rural, FCAV/UNESP, Jaboticabal - SP, rosalen@ fcav.unesp.br.

${ }^{2}$ Eng $^{\mathrm{Q}}$ Agrônomo, Mestre em Ciência do Solo, Doutorando em Produção Vegetal, FCAV/UNESP, Jaboticabal - SP, msalesrodrigues@gmail.com.

${ }^{3}$ Engo ${ }^{\circ}$ Agrônomo, Bolsista FAPESP, Doutorando em Ciência do Solo, FCAV/UNESP, Depto. de Engenharia Rural (LAMMA), Jaboticabal - SP, ca.chioderoli@uol.com.br.

${ }^{4}$ FCAV/UNESP Jaboticabal-SP, flaviabrandaob@yahoo.com.br.

${ }^{5}$ FCAV/UNESP, Departamento de Solos e Adubos, Jaboticabal - SP, diego_silvasiqueira@yahoo.com.br.

Recebido pelo Conselho Editorial em: 21-1-2011
}

Aprovado pelo Conselho Editorial em: 26-8-2011 


\section{INTRODUCTION}

The spatial variability characterization of soil attributes is essential to promote sustainable agricultural practices. MCBRATNEY et al. (2003) proposed the use of geostatistics, a numerical rating of tools to characterize spatial variability attributes, and improve mapping quality for agricultural and environmental purposes. Quality measurements in positioning are inferred especially through precision and accuracy indicators, such as standard deviation and mean square error, among others.

However, the result of geostatistical analysis of these attributes is dependent on sample density (CORÁ \& BERALDO, 2006) and other factors as the format of the sampling grid and the georeferencing method of the samples itself.

The georeferenced points, on the other hand, are directly related to the quality limits (isolines) presented by the spatial variability map (composing). Among the different georeferencing methods used in precision agriculture (PA), there is the Single Point Positioning (SPP), which uses receptors called "navigation" with expected accuracy of less than $15 \mathrm{~m}$ (GARMIN CORPORATION, 2006), and Relative Positioning (RP), which uses "geodetic" receptors (expected accuracy at the order of centimeters). It is noteworthy that, in determining the semivariance, paired sample points are used, which coordinates are provided by the positioning method adopted in the georeferencing; hence, the quality of these coordinates may affect the semivariogram results.

In study described by SHIRATSUCHI et al. (2004), GPS navigation showed adequate accuracy to regular grids with a minimum of $30 \mathrm{~m}$ in PA activities. DELALIBERA et al. (2007) claim that the use of GPS navigation in PA is dependent on the scale of study and knowledge of the variable to be georeferenced. In contrast, STABILE \& BALASTREIRE (2006) state that the GPS navigation receiver is not recommended for PA use, because it does not have adequate accuracy. These results indicate that the feasibility of using GPS navigation in PA is dependent on the application, as well as the desired accuracy. It is noticed that ROSALEN et al. (2010) determined an accuracy of about $4 \mathrm{~m}$ in planimetry for GPS navigation (Single Point Positioning).

Thus, studies seeking to evaluate the different methods of coordinate acquisition and its relation to characterization maps of soil properties at more detailed scales are important for PA application. Among these soil attributes, the mechanical resistance to penetration (RP), according to FREDDI et al. (2006), plays a major role on crop development, since root growth and crop productivity values are inversely proportional to RP. Therefore, it is of fundamental importance to understand the spatial distribution pattern of this attribute in defining specific areas of management.

It is important to say that RP is strongly correlated with soil moisture at sampling time and that this correlation is generally negative (MARTINS et al., 2009; ROSA FILHO et al., 2009). Therefore, it is also important to identify the spatial correlation of these variables. Thus, within this context; we aimed at comparing two georeferencing sample methods to characterize the spatial variability of soil mechanical resistance to penetration and gravimetric soil moisture as well as the spatial correlation of these variables.

\section{MATERIAL AND METHODS}

The study area is located in the municipality of Jaboticabal, state of São Paulo, approximately $21^{\circ} 15^{\prime} 22^{\prime \prime}$ South latitude and $48^{\circ} 18^{\prime} 58^{\prime \prime}$ West longitude, with an average altitude of $570 \mathrm{~m}$. The climate is classified according to Köeppen as subtropical dry winter (Cwa). The predominant soil is classified as a clayey Eutrudox Oxisol.

For measurements of soil mechanical resistance to penetration (RP), it was used an electronic penetrometer coupled to an ATV built in accordance with ASAE S313.3 norms (ASAE, 1999). A Dutch auger was used to sample gravimetric moisture (GM), which was determined according to the method described by EMBRAPA (1997). 
GM and RP were evaluated in the layer between 0.0 and $0.1 \mathrm{~m}$, following a sampling grid of 60 points spaced at $20 \mathrm{~m}$, with a total area of 1.8 ha. Twenty-meter spacing was adopted according to the accuracy of the GPS navigation used (less than $15 \mathrm{~m}$ to the Single Point Positioning method). The sampling grid was placed with stakes, using measuring tape. Later, the points were georeferenced using a Garmin GPS navigation receiver, model Etrex Vista, for Single Point Positioning (SPP), and geodetic Trimble L1GPS, model 4600LS for Relative Semi-Kinematic Positioning (RSKP). In Semi-kinematic positioning, $10^{\text {th }}$ elevation mask was used for static initialization of approximately $20 \mathrm{~min}$ and about $1 \mathrm{~min}$ per sampled point with fixed solution. Figure 1 displays the sampling scheme for both RP and GM, highlighting the coordinate differences of data points between the GPS receivers used.

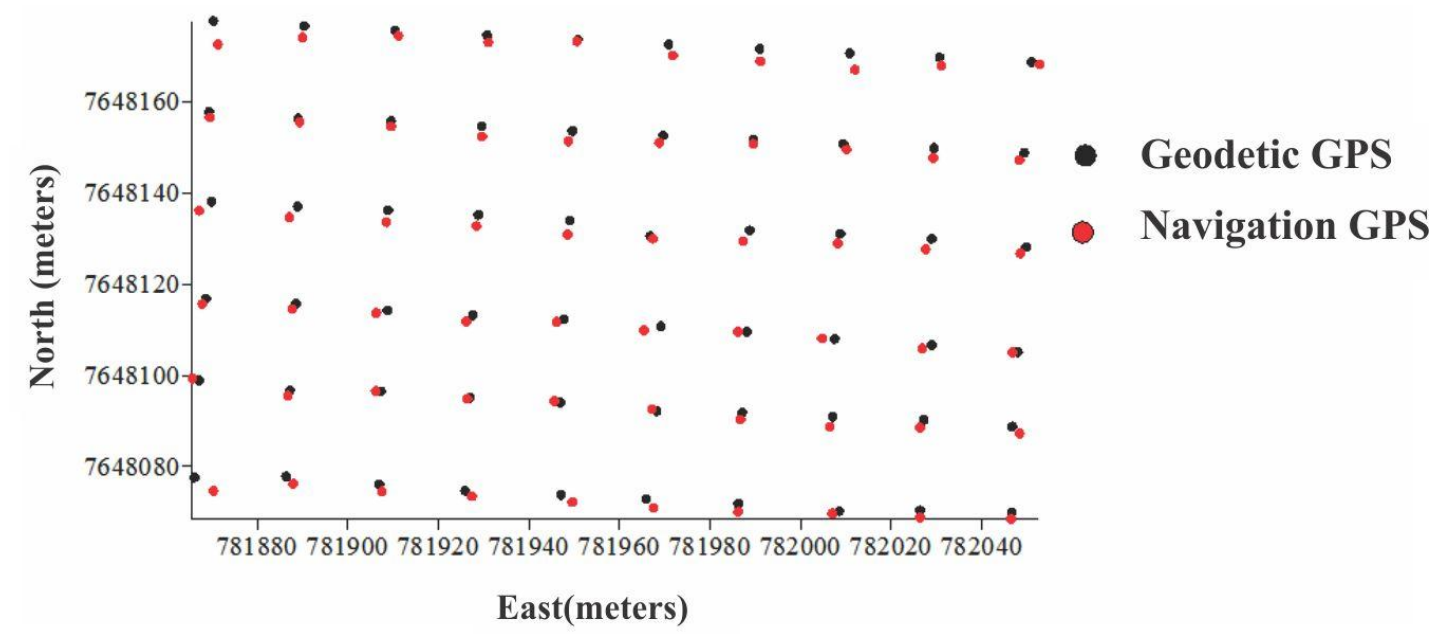

FIGURE 1. Sampling scheme for soil resistance to penetration (RP) and gravimetric soil moisture (GM) at a 0.0 to $0.1 \mathrm{~m}$ depth, using a geodetic and navigation GPS (plane-rectangular coordinates of UTM projection system, Zone 22, Reference System WGS84).

Data were submitted to descriptive statistical analysis to determine the average, maximum and minimum values, coefficient of variation (CV), and coefficients of skewness and kurtosis. The attribute variability was classified by the $\mathrm{CV}$ magnitude, according to PIMENTEL-GOMEZ \& GARCIA (2002), being low for CV values below 10\%, medium for CV between 10 and 20\%, high for CV between 20 and $30 \%$, and very high when CV was greater than $30 \%$.

To estimate the spatial dependence between samples, as well as to identify whether the changes were systematic or accidental, it was used semivariogram models. The selection of models was based on the lowest residual sum of squares (RSS) and best coefficient of determination $\left(\mathrm{R}^{2}\right)$. The semivariograms were validated by the cross validation method, observing isotropy in all adjusted models, which indicates that the spatial variability pattern of the structure is the same in all directions.

To analyze the degree of spatial dependence, it was used the classification according to CAMBARDELLA et al. (1994), which considers that the spatial dependence semivariograms has strong nugget effect when it equal to $25 \%$ of the baseline, moderate spatial dependence when the nugget effect is between 25 and $75 \%$, and weak spatial dependence when the nugget effect is greater than $75 \%$.

Subsequently, the estimation of experimental semivariograms and fitness of the theoretical models were performed to interpolate the data by the kriging method, using the $\mathrm{GS}^{+}$software (ROBERTSON, 2004). It was chose block kriging to generate maps with a smoother surface when compared to point kriging, since the former represents the average value of an area around the estimated point (BURROUGH \& MCDONNELL, 1998). For map preparation, the Surfer 8.0 program (SURFER, 2002) was used. To investigate the similarity between maps of the boundaries 
of soil RP and GM using the coordinates obtained by navigation and geodetic GPS, spatial correlation of the maps was performed through the criterion described by ROQUE et al. (2008).

In order to determine the linear correlation between GM and RP, it was performed simple Pearson correlation. To check the spatial correlation, cross-semivariograms were constructed, using $\mathrm{GM}$ as the main variable and RP as covariate. Only cross-semivariograms that had point series distributed in a single quadrant were selected, thus showing reliable property between GM and RP (MEGDA et al., 2008). Cross-semivariograms presenting point series in more than one quadrant were considered of indefinite spatial correlation (CAMARGO et al., 2008).

\section{RESULTS AND DISCUSSION}

Mean and median values for the variables of mechanical resistance to penetration (RP) and gravimetric soil moisture (GM) were close, indicating symmetric distributions (Table 1). Similar results were obtained by ROSA FILHO et al. (2009) in a dystrophic Oxisol under no-tillage system. RP showed very high variability, per its CV, as suggested by PIMENTEL-GOMEZ \& GARCIA (2002), agreeing with the results obtained by RAMÍREZ-LÓPEZ et al. (2008) in a Typic Haplustox, but contradictory to results reported by ROSA FILHO et al. (2009), who observed average variability for RP. Observing the CV values, there is average variability for GM. Similar results were observed in a study by FREDDI et al. (2006) in a dystrophic Oxisol under conventional tillage.

TABLE 1. Results of statistical analysis of soil resistance to penetration (RP) and gravimetric soil moisture $(\mathrm{GM})$ in 0.0 to $0.1 \mathrm{~m}$ depth.

\begin{tabular}{lcc}
\hline Statistic & RP $(\mathrm{MPa})$ & GM $\left(\mathrm{kgkg}^{-1}\right)$ \\
\hline Average & 2.64 & 0.274 \\
Median & 2.45 & 0.277 \\
Minimum & 0.68 & 0.162 \\
Maximum & 6.34 & 0.351 \\
Coefficient of Variation $(\%)$ & 53 & 11 \\
Coefficient of asymmetry & 0.87 & -1.26 \\
Coefficient of Kurtosis & 0.41 & 5.00 \\
\hline
\end{tabular}

RP semivariograms estimated with geodetic GPS coordinates and with navigation GPS presented similar parameters, and the adjusted model used for both was spherical (Table 2). There was a lower value for the parameter nugget effect $\left(\mathrm{C}_{0}\right)$ in the semivariogram obtained with geodetic GPS coordinates in comparison with the one estimated from navigation GPS coordinates for RP. However, based on the classification by Cambardella et al. (1994), the degree of spatial dependence was strong for both semivariograms. The range of the geodetic GPS semivariogram for RP was $2 \mathrm{~m}$ greater than the navigation GPS (Table 2).

The exponential model was used to fit the data for the GM semivariogram. So, as for RP, the widest range found for the GM semivariogram $(66 \mathrm{~m})$ was estimated with coordinates from the geodetic GPS receiver. The degree of spatial dependence (DSD) for GM was classified as strong (Table 2). There was only a small difference between the results obtained using the navigation and the geodetic GPS receivers in the RP and GM semivariograms. This result indicates that the coordinates obtained with the navigation GPS receiver were adequate for determining the RP and the GM spatial distribution patterns in this study. 
TABLE 2. Estimated models and parameters of semivariograms adjusted to data of soil resistance to penetration (RP) and gravimetric soil moisture (GM) at 0.0 to $0.1 \mathrm{~m}$ depth.

\begin{tabular}{lccccccc}
\hline Attribute & Model & $\mathrm{C}_{0}$ & $\mathrm{C}_{0}+\mathrm{C}$ & $\mathrm{a}(\mathrm{m})$ & GDE & $\mathrm{R}^{2}$ & $\mathrm{RSS}$ \\
\hline RP Navigation GPS & Spherical & 0,186 & 1,910 & 33 & Forte & 0,158 & 0,215 \\
RP Geodetic GPS & Spherical & 0,050 & 1,970 & 35 & Forte & 0,162 & 0,361 \\
GM Navigation GPS & Exponential & $3,7 \times 10^{-5}$ & $30,5 \times 10^{-5}$ & 62 & Forte & 0,324 & $10,6 \times 10^{-9}$ \\
GM Geodetic GPS & Exponential & $4,2 \times 10^{-5}$ & $30,8 \times 10^{-5}$ & 66 & Forte & 0,384 & $9,6 \times 10^{-9}$ \\
\hline
\end{tabular}

$\mathrm{C}_{0^{-}}$Nugget effect; $\mathrm{C}_{0}+\mathrm{C}$-Baseline; a - Range; DSD- Degree of spatial dependence; $\mathrm{R}^{2}$ - Coefficient of determination; RSS Residual sum of squares.

Interpolation by kriging generated 5,641 estimated points. Note in Figure 2 the similarity between maps obtained with the coordinates from geodetic and navigation GPS for both RP (Figures $2 \mathrm{a}$ and $2 \mathrm{~b}$ ) and GM (Figures $2 \mathrm{c}$ and $2 \mathrm{~d}$ ). The extent of this similarity is indicated by the values of spatial correlation obtained between RP and GM maps, based on navigation and geodetic GPS coordinates. The correlation values obtained were 0.992 for RP and 0.900 for GM. These results indicate that even with the changes in the semivariogram parameters, the method used to acquiring coordinates was not significant to map RP and GM variabilities. Therefore, it is possible to use navigation GPS to find the spatial distribution pattern of RP and GM, and to define the limits of uniform management areas (specific management areas) with satisfactory reliability.

These results are consistent with those obtained by SHIRATSUCHI et al. (2004), which also analyzed the feasibility of using the navigation GPS for precision farming activities, provided they use regular grids spaced at a minimum of $30 \mathrm{~m}$. However, in the present study, it was observed that even with the use of grids with points spaced at $20 \mathrm{~m}$, it was possible to confirm the reliability of navigation GPS. This result is important because navigation GPS may become economically viable for uses in precision farming activities, since these receptors are cheaper compared to the receivers known as having better precision and accuracy, such as the geodetic GPS receivers.

Navigation GPS

a. RP (MPa)

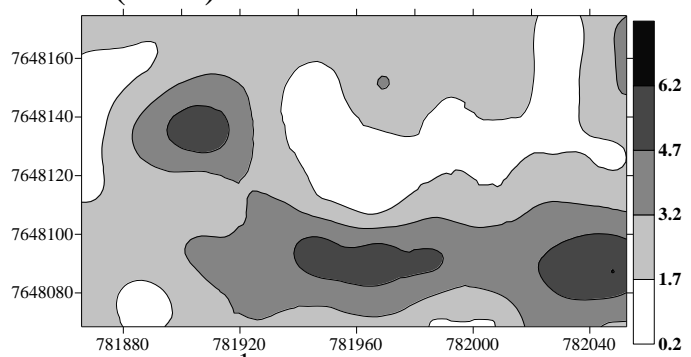

c. $\mathrm{UG}\left(\mathrm{kg} \mathrm{kg}^{-1}\right)$

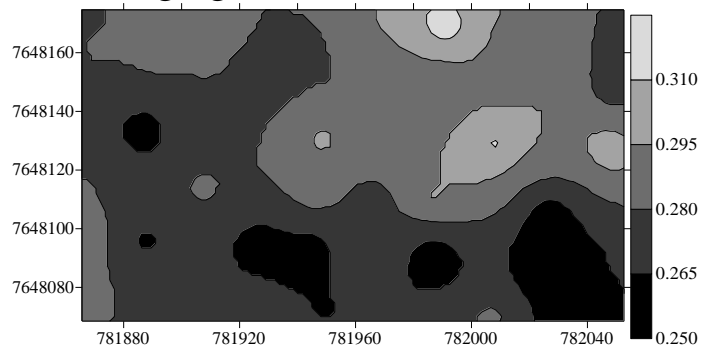

Geodetic GPS

b. RP (MPa)

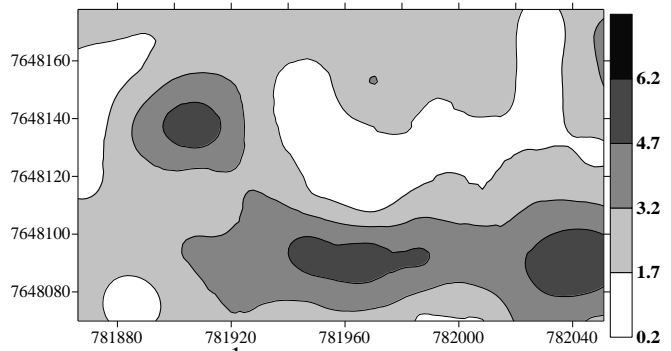

d. $\mathrm{UG}\left(\mathrm{kg} \mathrm{kg}^{-1}\right)$

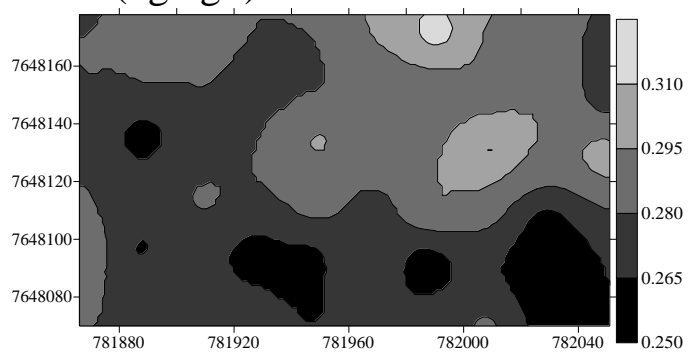

FIGURE 2. Maps of spatial distribution of soil resistance to penetration (RP) (a, b) and gravimetric soil moisture $(\mathrm{GM})(\mathrm{c}, \mathrm{d})$ at a 0.0 to $0.1 \mathrm{~m}$ depth.

The coefficient of correlation (r) between GM and RP was $-0.3(\mathrm{p}<0.05)$, indicating that there was an inverse correlation between these variables. Similar result was obtained by MARTINS et al. (2009), who also noted inverse correlation between GM and RP in a dystrophic Oxisol under no- 
tillage. It was possible to estimate cross-semivariograms when using coordinates obtained by geodetic GPS receiver as well as with the navigation GPS receiver (Figure 3). Corroborating the results of linear correlation analysis, it appears that the spatial correlation between the GM and RP is inversely proportional. The adjusted model for both cross-semivariograms was exponential. These results agree with those obtained by ROSA FILHO et al. (2009), who also noted negative spatial correlation between GM and RP; however, the adjusted model in that was the spherical.

The parameters nugget effect $\left(\mathrm{C}_{0}\right)$ and baseline $\left(\mathrm{C}_{0}+\mathrm{C}\right)$ were similar for both crosssemivariograms. The parameter range in the cross-semivariogram, unlike the simple semivariogram, represents the end or the maximum distance of spatial dependence between the variables (VIEIRA, 2000). Thus, for the present study, the spatial dependence between GM and RP was $62 \mathrm{~m}$ for the cross-semivariogram estimated with data obtained by the navigation GPS receiver and $63 \mathrm{~m}$ for the geodetic receiver. These results indicate that the spatial structure of the cross semivariogram was virtually unchanged by using coordinates obtained from different positioning methods. Therefore, it can be conclude that it is possible to use coordinates obtained by the navigation GPS (Single Point Positioning) system to determinethe codependency of GM and RP variables.

a) Navigation GPS

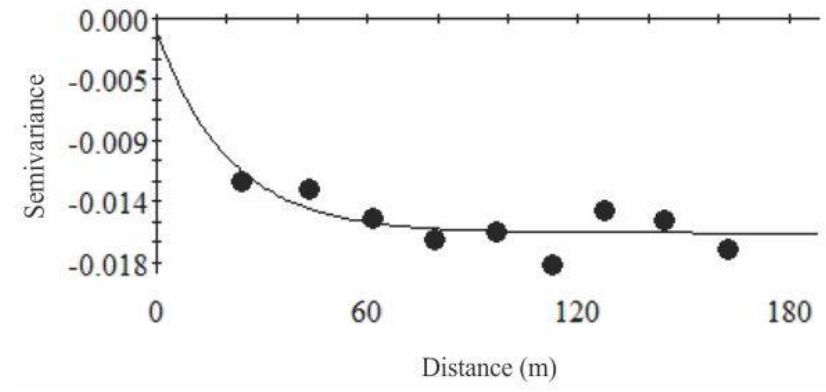

$\operatorname{Exp}\left(C_{0}=-0,0010 ; C_{0}+C=-0,0162: a=62 \mathrm{~m} ; \mathrm{RSS}=1,488 \times 10^{-5}\right.$; $\left.\mathrm{R}^{2}=0,552\right)$ b) Geodetic GPS

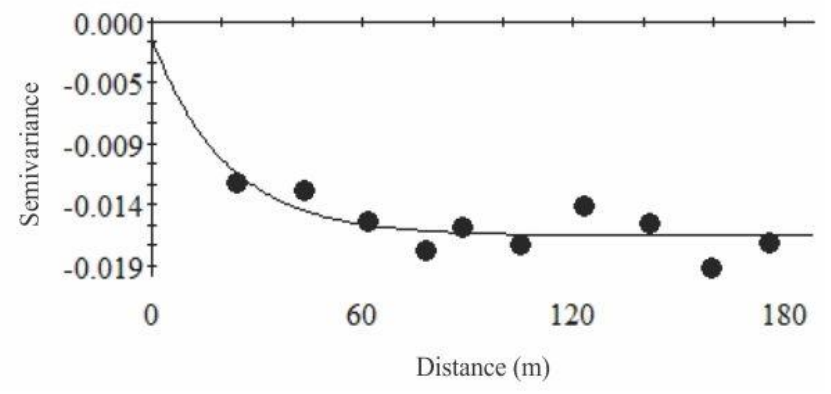

$\operatorname{Exp}\left(C_{0}=-0,0013: C_{0}+C=-0,0165: a=63 \mathrm{~m}: R S=1,830 \times 10^{-5}:\right.$ $\left.\mathrm{R}^{2}=0,532\right)$

FIGURE 3. Cross semivariograms between the soil gravimetric moisture and soil resistance to penetration, using coordinates from navigation GPS (a) and a geodetic GPS receiver (b). Exp- Exponential; $\mathrm{C}_{0}=$ Nugget effect, $\mathrm{C}_{0}+\mathrm{C}$-Baseline, a- Range; RSS-Residual sum of squares; $\mathrm{R}^{2}$ - Coefficient of determination.

\section{CONCLUSIONS}

Within the experimental conditions, it can be conclude that the sample georeferencing using navigation GPS (Single Point Positioning) did not affect the characterization of the spatial variability of soil mechanical resistance to penetration (RP) or the gravimetric soil moisture (GM) at the layer of 0.0 to $0.1 \mathrm{~m}$ depth, indicating that this positioning method may be used for georeferencing to characterize the variability in a ultra-detailed scale $(\geq 1: 5,000)$.

The spatial structure of the relationship of the attributes gravimetric moisture (GM) and soil mechanical resistance to penetration (RP) was not altered by using coordinates in the two different positioning methods analyzed (navigation GPS - Single Point Positioning, and L1 geodetic GPS Relative Semi-KinematicPositioning). Thus, within the experimental conditions, coordinates obtained by navigation GPS maybe used to determine the codependency of variables related to gravimetric soil moisture and soil mechanical resistance to penetration.

\section{REFERENCES}

ASAE - AMERICAN SOCIETY OF AGRICULTURAL ENGINEERS. ASAE S313.3 soil cone penetrometer. St. Joseph, 1999. p.834-835. 
BURROUGH, P.A.; MCDONNELL, R.A. Principles of geographical information systems.Oxford: University Press, 1998. 333 p.

CAMARGO, L.A.; MARQUES JUNIOR, J.; PEREIRA, G.T.; HORVAT, R.A. Variabilidade espacial de atributos mineralógicos de um latossolo sob diferentes formas do relevo: II - Correlação espacial entre mineralogia e agregados. Revista Brasileira de Ciência do Solo, Viçosa-MG, v.32, n.6, p.2279-2288, 2008.

CAMBARDELLA, C.A.; MOORMAN, T.B.; NOVAK, J.M.; PARKIN, T.B.; KARLEN, D.L.; TURCO, R.F.; KONOPKA, A.E. Field-scale variability of soil properties in central Iowa soils. Soil Science Society of American Journal, Madison, v.58, n.5, p.1501-1511, 1994.

CORÁ, J.E.; BERALDO, J.M.G. Variabilidade espacial de atributos do solo antes e após calagem e fosfatagem em doses variadas na cultura de cana-de-açúcar. Engenharia Agrícola, Jaboticabal, v.26, n.2, p.374-387, 2006.

DELALIBERA, H.C.; WEIRICH NETO, P.H.; EURICH, J.; LOPES, A.R.C. Incerteza e precisão de um receptor manual de sinal de satélites (Sistema NAVSTAR-GPS), sem correção diferencial. Publicatio UEPG, Ciências Exatas, da Terra, Agrárias e Engenharias, Ponta Grossa, v.13, n.1, p.35-40, 2007.

EMBRAPA - EMPRESA BRASILEIRA DE PESQUISA AGROPECUÁRIA. Manual de métodos de análise de solo. 2.ed. Rio de Janeiro: Centro Nacional de Pesquisa de Solos, 1997. 212 p.

FREDDI, O.S.; CARVALHO, M.P.; VERONESI JÚNIOR, V.; CARVALHO, G.J. Produtividade do milho relacionada com a resistência mecânica à penetração do solo sob preparo convencional. Engenharia Agrícola, Jaboticabal, v.26, n.1, p.113-121, 2006.

GARMIN CORPORATION. Etrex Vista Cxowner's manual. Taipei County, 2006. 112 p. (Manual Técnico).

MARTINS, M.V.; CARVALHO, M.P.; ANDREOTTI, M.; MONTANARI, R. Correlação linear e espacial entre a produtividade do feijoeiro e atributos físicos de um Latossolo Vermelho distroférrico de Selvíria, Estado de Mato Grosso do Sul. Acta Scientiarum Agronomy, Maringá, v.31, n.1, p.147-154, 2009.

MCBRATNEY, B.; SANTOS, M.L.M.; MINASNY, B. On digital soil mapping. Geoderma, Amsterdam, v.117, n.1-2, p.3-52, 2003.

MEGDA, M.M.; CARVALHO, M.P.; VIEIRA, M.X.; ANDREOTTI, M.; PEREIRA, E.C. Correlação linear e espacial entre a produtividade de feijão e a porosidade de um Latossolo Vermelho de Selvíria (MS). Revista Brasileira de Ciência do Solo, Viçosa-MG, v.32, n.2, p.781788, 2008.

PIMENTEL-GOMEZ, F.; GARCIA, C.H. Estatística aplicada a experimentos agronômicos e florestais: exposição com exemplos e orientações para uso de aplicativos. Piracicaba: FEALQ, 2002. 309 p.

RAMÍREZ-LÓPEZ, L.; REINA-SÁNCHEZ, A.; CAMACHO-TAMAYO, J.H. Variabilidad espacial de atributos físicos de Typic Haplustox de los llanos orientales de Colômbia. Engenharia Agrícola, Jaboticabal, v.28, n.1, p.55-63, 2008.

ROBERTSON, G.P. Release 7. GS+: geostatistics for the environmental sciences. Gamma Design Software. Plainwell, 2004.

ROQUE, M.W.; MATSURAII, E.E.; SOUZA, Z.M.S.; BIZARI, D.R.; SOUZA, A.L. Correlação linear e espacial entre a resistência do solo ao penetrômetro e a produtividade do feijoeiro irrigado. Revista Brasileira de Ciência do Solo, Brasília, v.32, n.5, p.1827-1835, 2008.

ROSA FILHO, G.; CARVALHO, M.P.; ANDREOTTI, M.; MONTANARI, R.; BINOTTI, F.F.S.; GIOIA, M.T. Variabilidade da produtividade da soja em função de atributos físicos de um 
Latossolo Vermelho distroférrico sob plantio direto. Revista Brasileira de Ciência do Solo, ViçosaMG, v.33, n.2, p.283-293, 2009.

ROSALEN, D.L.; TAKAHASHI, K.M.; GONÇALVES, K.C. Avaliação da precisão, tendência e acurácia de receptores GPS de navegação para fins de agricultura de precisão. In: CONGRESSO BRASILEIRO DE AGRICULTURA DE PRECISÃO, 2010, Ribeirão Preto. Anais ... Jaboticabal: Associação Brasileira de Engenharia Agrícola, 2010. 1 CD-ROM.

SHIRATSUCHI, L.S.; ZIVIANI, A.C.; MARTINS, F.S. Comparação de modelos receptores GPS para utilização na Agricultura de Precisão. Planaltina: Embrapa Cerrados, 2004. p.5. (Comunicado Técnico, 112).

STABILE, M.C.C.; BALASTREIRE, L.A. Comparação de três receptores GPS para uso em agricultura de precisão. Engenharia Agrícola, Jaboticabal, v.26, n.1, p.215-223, 2006.

SURFER. Release 8.0. Contouring and 3D surface mapping for scientist's engineers: User's Guide. New York: Golden software, 2002. 619 p.

VIEIRA, S.R. Geoestatística em estudos de variabilidade espacial do solo. In: NOVAIS, P.F.; ALVAREZ, V.H.; SCHAEFER, C.E.G.R. Tópicos em ciência do solo. Viçosa: Sociedade Brasileira de Ciência do Solo, 2000. v.1. p.1-54. 